\title{
The Effect of Transformation Leadership, Motivation, and Work Ethos on Employee Performance
}

\author{
Rahmat Hidayat \\ Pelita Bangsa University \\ rahmat hidayat@pelitabangsa.ac.id
}

\begin{abstract}
Today, every company, both large and small, is trying to improve the performance of its employees. Not only companies, government agencies are also doing something. They try to improve employee performance in order to get a good assessment from the central government and public satisfaction and trust. Human resources are one of the important factors in any organizational activity, both private and government. This can be achieved through targeted and planned human resource development efforts. Apart from the leadership role, motivation and work ethic can affect the performance of employees in the village. The research aims to study the role of transformational leadership, motivation and work ethic on performance. To analyze data, researcher uses validity and reliability test. Next, researcher analyze it using classic assumption, multiple linear regression, and hypothesis test. Determination coefficient test (adjusted R2) is also used in this research. Based on the results obtained by the equation multiple linear regression analysis, the results of $t$ - test showed the value of t-test is greater than the value that is significant, which means that the first hypothesis is accepted. From the transformation of leadership and performance, the motivation variable obtained the results is smaller than the significant value, which means that the second hypothesis is rejected and shows that there is no significant influence between motivation on performance. The work ethic variable obtained by the test results is greater than the significant value, which means the last hypothesis is accepted and shows that there is a influence between work ethic on performance and we could take conclusion that the contribution of transformational leadership, motivation and work ethic to performance. The performance together is $56 \%$ while the remaining $44 \%$ is influence effected by other variables.
\end{abstract}

Keywords: Transformational Leadership, Motivation, Work Ethics, Performance

\section{Introduction}

Human resources are one of the most important and major factors in any organizational activity, both private and government. Quality human resources can be achieved through targeted and planned human resource development efforts. Efforts to develop human resources are activities that must be carried out by every organization or institution, so that the capabilities and attitudes of human resources are more in line with work guidelines and the needs of the organization or agency. Human resource development programs can be carried out in various techniques or ways, including by providing motivation, increasing work ethic, giving awards for work performance, promotions, transfers, incentives and providing educational and training opportunities. 
Village government organizations are the lowest level of government in the government structure in Indonesia but have roles and functions in implementing government programs. Village official is one element important in the village administration and should have the ability to perform well for support services to people with better due to the success of an organization or institution in achieving a goal is highly dependent on the ability and willingness of human resources itself to increased

The role of leaders in an organization can affect the morale of organizational members, the quality of work of organizational members, and the level of achievement of organizational members. Therefore, transformational leadership is leadership that inspires its followers to put aside personal interests and have the ability to influence beyond the ordinary . [1]

Transformational leadership can feel that followers feel trust, admiration, loyalty and respect for the leader and are motivated to do something more than expected [2] illustrated in their research that Transformational leadership is not merely directive, but is related to follower development and performance.

Transformational leadership is considered effective in improving employee performance, this can be explained through the four components of transformational leadership, namely idealized influence, individual consideration , inspirational motivation, and intellectual stimulation. Leaders who apply transformational leadership styles can improve employee performance, such as the results of research [3] that transformational leadership affects employee performance. In leadership, basically every employee must have selfmotivation because performance motivation will not emerge by itself but must be determined from within the employee and motivation can be interpreted as a mental state and human mental attitude that provides energy and encouragement. activity ( moving), and leading or channeling behavior toward the achievement of needs that provide satisfaction or reduce imbalance [4].

[4] stated that motivation is important because with this motivation it is expected that each individual employee will work hard and be eager to achieve high productivity. This statement is reinforced by the research of Eka, Septiana Nata (2015) in Syahida and Syriac (2018) on the effect of work motivation on the performance of village officials shows a positive effect. According to [5] states that work motivation consists of three important components, namely the energy component, the steering component and the maintenance component.

In addition to transformational leadership and motivation, there is also one factor that can affect employee work levels, namely work ethic, because work ethic is a set of basic attitudes or views held by employees to assess work as a positive thing for improvement. quality of life so that it will affect work behavior in an organization. Employees who have a good work ethic will try to show attitude, character and self-confidence in carrying out a job by acting and working optimally besides that there are several elements that are able to measure the extent to which work ethics affects the performance of an employee, namely Hard Work, Discipline, Honest And Responsibility. Results of research conducted by [6] The show's work ethic has a positive and significant effect on employee performance.

Based on the description of the phenomenon and previous research relevant to the research phenomenon, the title " The Influence of Transformational Leadership, Motivation and Work Ethics on Employee Performance." 


\section{Research purposes}

Based on the problems that have been formulated above, the objectives to be achieved in this study are to examine and determine the Effect of Transformational Leadership, High Motivation and the Effect of Work Ethics on Employee Performance.

\section{Literature Review}

Performance can be assumed as a result of a process or work. Therefore, every employee is required to have competence, namely the ability to carry out tasks or jobs that are their responsibility or entrusted. Every task or implementation of work contains activities to process or convert inputs into value-added outputs as products or works.

Employee performance or work performance is the work's quality and quantity accomplished by a worker in carrying out their obligation in accordance with his responsibility. [7] states, which meant performance was the work that is generated by employees who displayed In accordance with its role to achieve a goal .

Performance was the work given by an employee related to the duties and responsibilities to the organization which is based on spiritual intelligence, emotional intelligence and intelligence transforms barriers into opportunities and physical skills that are directed at exploiting the resources provided by the organization (company).

So based on this definition it can be concluded that performance is work's result which is has quality and quantity reached by workers, to do the obligation that the organization obligates to him. The result of obligation are suitable to expectations of organization, through the rule that applied by the place of working. The target of organizational achievement is influenced by the performance of individuals and groups of employees .

According to [1] the transformational leadership has the vision to increase and could know the situation and condition in an organization, the cutting edge of change and provide motivate and inspire for individual workers to have idea to build cooperation team is solid, bring renewal in work ethic and performance management, courageous and responsible for leading and controlling the organization. Meanwhile, according to [3] this kind of leadership includes how to develops a good relationship among workers, manager and other sections. They should have the same commitment about the organization or institution they work.

This kind of leadership is leadership that inspires followers to put self-interest aside and have extraordinary influencing abilities [1 ] . In this leadership, the workers will fell trust to the organization, loyal, respect and admiration. They will be creative in working and the organization could get the target [8]. According to [9], it is stated that transformational leaders manage the organization by inspiring, motivating and empowering employees to produce organizational success. This means that transformational leaders manage organizations by inspiring, motivating and empowering their employees to be successful in doing their jobs.

From the transformational leadership theory put forward by experts, it can be concluded that transformational leadership is the ability of a leader to direct, influence, and motivate his subordinates to work to achieve organizational interests and goals.

In a general sense, motivation is to achieve a specific goal. In line with [10] it is said that motivation is an impulse that appears on or in individuals who drive and direct behavior. According to [11]. Work motivation is a condition or energy that encourages employees to be directed or directed to achieve company organizational goals. 
According to [12] motivation in work of a worker is the result of employee work that will arise because of the encouragement from within the worker concerned as a result of the integration of personal needs as a whole, the influence of the physical environment and the social environment influences whose bee good suitable with the process of integration.

The above statement is also supported by the opinion [12] that if workers have the motivation to achieve their personal goals, then they must improve performance. Improving performance will also improve organizational performance. Thus, increasing employee motivation will improve individual, group and organizational performance.

In an organization, motivation is very important and therefore according to [13] it is stated that motivation is a process in internal that makes a worker move by good action. He added that motivation, like intelligence, cannot be observed directly. [14] Shows that, motivation is a process in internal that makes a worker move towards something destination. [15] Said that motivation, like intelligence, cannot be observed directly.

Ethos comes from the Greek word ethos which means attitude, personality, character, character, and belief in something [16]. This attitude is not only owned by individuals, but also by groups and even communities. Work ethic is an attitude arising from one's own willingness and awareness which is based on a cultural value orientation system towards work [19]. Ethos is formed by various customs, cultural influences, and value systems that he believes in [ 20 ].

According to [21], work ethic is the totality of a person's personality and how to express, view, believe and give meaning to something, which encourages him to act and achieve optimal charity. Employees who have a good work ethic will try to show attitude, character and confidence in carrying out a job by acting and working optimally.

According to [22] it is stated that work ethic is a set of positive work behaviors rooted in strong cooperation, fundamental beliefs, accompanied by total commitment to an integrated work paradigm. According to him, if a person, organization or community adheres to the work paradigm, is trustworthy, and is committed to the work paradigm, all of these will create unique work attitudes and behaviors. It will become a work culture. Employee performance in carrying out work is also influenced by motivation and work ethic because motivation and internal work ethic factors play a very important role in carrying out employees' daily tasks.

\section{Hypothesis}

The hypothesis in this scientific paper, with the theme The Influence of Transformational Leadership, Motivation and Work Ethics on Employee Performance is as follows:

First Hypothesis: Transformational leadership style can affect employee performance.

Hypothesis Two: Motivation can affect employee performance

Hypothesis Three: Work ethics can affect performance 


\section{Research Methodology}

In the preparation of this thesis the author uses a type of quantitative research, namely research used to answer problems through careful measurement techniques for certain variables, so as to produce generalizable conclusions, regardless of the time context and situation and type. the data collected is mainly quantitative data [24]. Data in quantitative research is the result of measuring variables that are operated using instruments. In analyzing the data, research using quantitative methods is examined at the end of data collection.

Based on the title studied," The Influence of Transformational Leadership, Motivation and Work Ethics on Employee Performance ", the author wanted to know whether there was an influence between transformational leadership, motivation and work ethic on employee performance in Bekasi. District.

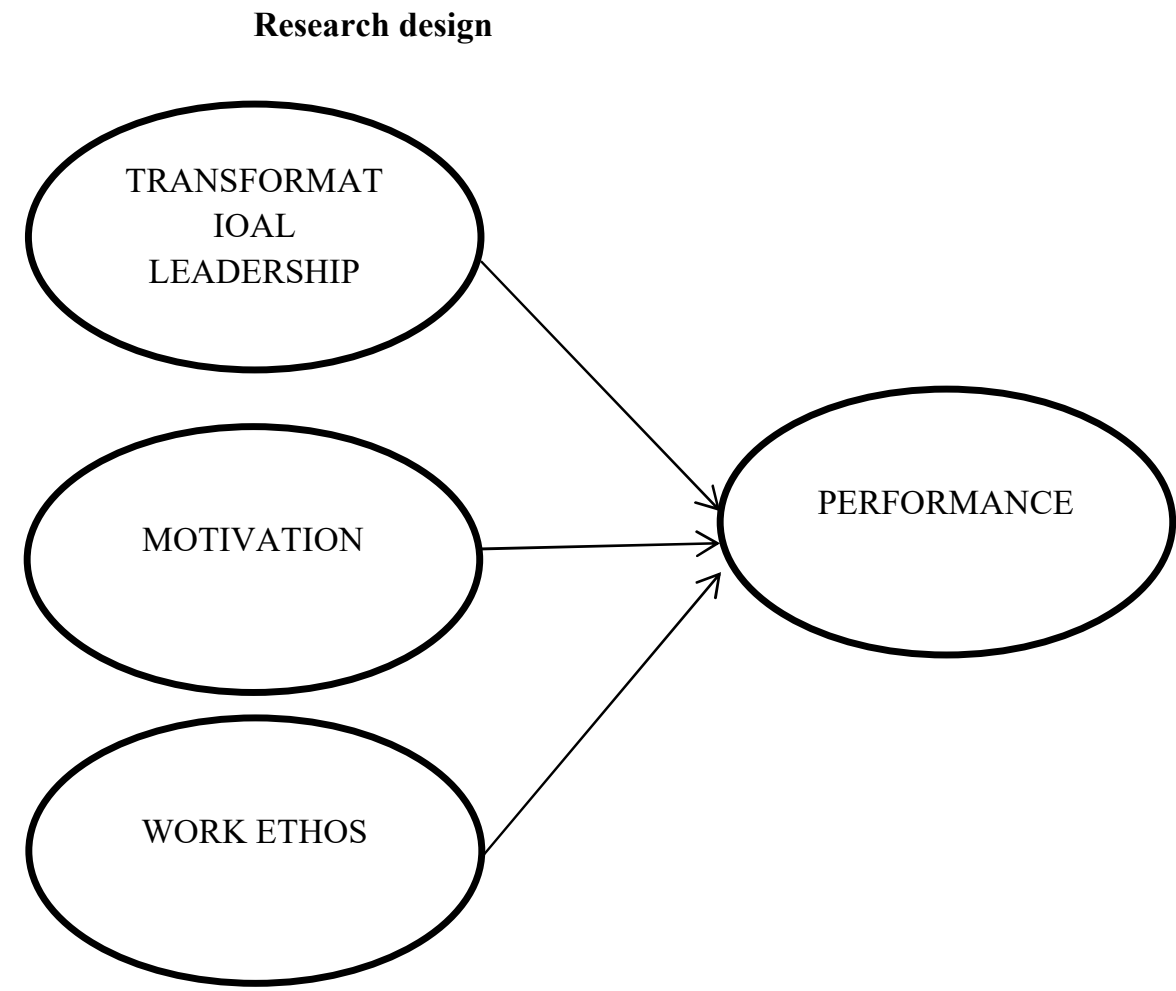

Methods nonprobability sampling that is used is the technique of sampling saturated, saturated sampling is the technique of sampling that all members of the population sampled. This is because the population is small, less than 30 people [ 25 ]. Another term for saturated sampling is census, where all of the population is used as a sample. Based on this opinion, the researcher took a sample of 40 employees representing the total population. 
The data collection methods used in this study are as follows:

1. Observations, observations / observations are made directly in the village as the object of research on transformational leadership , motivation and work ethic on employee performance.

2. Questionnaire data, data collection by distributing questionnaires containing questionnaires about transformational leadership, motivation, work ethic were given to 40 employees using a respondent rating scale 1-5, where a scale of 1 (strongly disagree) to a scale of 5 (strongly agree).

3. Literature study, carried out by collecting articles, relevant theories, and other literature related to this research

\section{Results and Discussions}

The validity test is used to measure the speed of an item in the questionnaire whether it is appropriate in measuring what you want to measure. Valid items are indicated by a significant correlation between the items and the total item score. To determine the appropriateness of an item is used or not, to test the significance of the correlation coefficients at levels significantly to the total core items such . [ 24 ]

Significance test is to compare $r$ count with $r$ table for value level. Based on the results of these calculations, it can be seen that $r_{\text {count }}>r_{\text {table }}$ is $N=40$ with a significant level of $5 \%$, namely 0.320 , so it can be said that the variable work ethic used in research is valid. Valid statements can be used in data collection.

Testing the reliability of all items or statements used in this study using the Cronbach's Alpha $(\alpha)$ statistical test . A variable is said to be reliable if the value is above 0,6 (eg 0.7 is acceptable or above 0.8 is good) it can be concluded that variable is reliable. Of trials that have been done can be seen that the results of Cronbach's Alpha for each - each variable over a specified minimum standard is 0.6 then the variable employee performance, transformational leadership, motivation and work ethic can be said to be reliable.

The normality test is used to test whether the value generated from the regression model is normally distributed or not. Normality testing is done by using the KolomogorovSimirnov test. The data distribution is said to be normal if the Significant value (Sig) is more than 0.05 . Based on the Significant value test (Sig) on Komologorov- Smirnov of 0.153 because the significance value is greater than 0.05 , it can be said that the data has been normally distributed.

The multicollinearity test aims to determine whether the regression model found a correlation between the independent variables or not. To determine the presence or absence of multicollinearity in the regression model, it can be used by analyzing and seeing the value of the Variance Inflation Factor (VIF) and the tolerance value of the independent variable on the dependent variable. A model is said to be free from multicollinearity if VIF is less than 10 and more tolerance of 0,1 then the regression model expressed freely multicollinearity. Based on testing that the value tolerance of all variables over 0,1 and VIF $<10$ it can be concluded that the regression equation is free from multikolinearity.

Test heteroscedasticity used to test whether there is a variance in the regression model residuals are not the same from one observation to another observation. The way to test the presence or absence of heteroscedasticity is to use glare test. The regression model 
said that heteroscedasticity did not occur if the significance value was $>0.05$. Based on the test that all variables show significant results because the significant value is greater than 0.05 , it means that it can be concluded that the regression equation does not occur heteroscedasticity .

\section{A Linear Regression analysis}

Based on the calculation of multiple linear regression analysis carried out through statistics using the SPSS program, the following data are obtained:

\section{Coefficient a}

\begin{tabular}{|l|r|r|r|r|r|}
\hline \multirow{2}{*}{ Model } & \multicolumn{2}{|c|}{ Nonstandard Coefficient } & \multicolumn{1}{c|}{$\begin{array}{c}\text { Standard } \\
\text { Coefficient }\end{array}$} & & \\
\cline { 2 - 4 } & \multicolumn{1}{|c|}{ B } & Std. Error & \multicolumn{1}{c|}{ Beta } & \multicolumn{1}{c|}{ T } & \multicolumn{1}{c|}{ Sig. } \\
\hline 1 (Constant) & 18,638 & 4,710 & & 3,957 & .000 \\
LEADERSHIP & & & & & \\
TRANSFORMATION & 0.287 & 0.121 & 0.290 & 2,381 & 0.023 \\
MOTIVATION & -306 & 0.179 & -298 & $-1,712$ & 0.095 \\
WORK ETHIC & 0.712 & 0.164 & 0.798 & 4,339 & .000 \\
\hline
\end{tabular}

1. A Constanta of 18.638 means that if the value of transformational leadership, motivation and work ethics is 0 (zero) it means that the performance is 18.638 .

2. The regression coefficient of variable Transformational Leadership is 0,287: it means that if the Transformational Leadership has risen one point, performance improves 0,287 points assumption of independent variable sit were fixed value.

3. The regression coefficient for the motivation variable is -0.306 : it means that if the motivation has decreased by one point, then the performance will decrease by -0.306 points, assuming the independent variable has a fixed value.

4. The regression coefficient for the Work Ethics variable is 0.712 , which means that if the Work Ethic increases by one point $t$, then the performance will increase by 0.712 points, assuming other independent variables have a fixed value.

The $t$ test was conducted on partial hypothesis testing, to determine whether there was a partial influence of the independent variables (transformational leadership, 
motivation and work ethic) on the dependent variable (performance). T test results can be seen in as follows:

Based on the test, it can be seen that the significance value of the transformational leadership variable is $0.023<0,05 . \mathrm{t}$ count 2,338 and $\mathrm{t}$ table value 2,028 where ( df ) nkl or 40-3-1 = 36 with two-sided test (significance 0.025 ) so it is known $\mathrm{t}_{\text {count }}>$

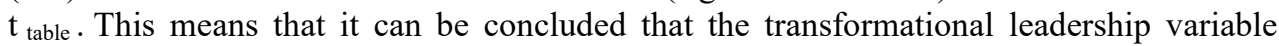
partially has a significant positive effect on performance, meaning that Ho is rejected while Ha is accepted and the first hypothesis is accepted.

It can be seen that the significance value of the motivation variable is $0.095>0.05$. It is known that $t$ count $-1,712$ and $t$ table value of 2,028 where ( $\mathrm{df}$ ) $\mathrm{nkl}$ or $40-3-1=36$ by two-sided test (significance 0.025) so that it is known that $\mathrm{t}_{\text {count }}<\mathrm{t}_{\text {table }}$. This means that it can be concluded that the motivation variable partially has no significant and negative effect on performance, which means that Ho is accepted while $\mathrm{Ha}$ is rejected and the second hypothesis is rejected.

We could find that the significant value of the work ethics variable is 0.000 $<0.05$. It is known that the tcount is 4.339 and the $\mathrm{t}$ table value is 2.028 where ( df ) nkl or $40-3-1=36$ with a two-sided test ( 0.025 significance) so that it is known that $t_{\text {count }}>\mathrm{t}_{\text {table }}$. This means we could conclude that the variable of work ethic, partially has a significant positive effect on performance, so we know that Ho is rejected while Ha is accepted and the third hypothesis is accepted.

The coefficient of determination is used by researcher determine the score of the contribution of the influence of all $\mathrm{X}$ variables simultanly on $\mathrm{Y}$ variable. We could see the score of the determination in the summary of the output model from the results of multiple linear regression analysis. We could see the score of the test of coefficient of determination as follows:

After we calculate, we known that the Adjusted R Square score is 0.560 . So we could take the conclusion that the contribution of leadership (transformational), motivation and work ethic to performance together is $56 \%$ while the remaining $44 \%$ is effected by other variables not included in this study.

\section{Conclusion}

From all discussions that we have described, the following conclusions can be drawn:

1. The transformational leadership variable has a positive and significant effect, which means that transformational leadership has an effect on employee performance

2. The motivation variable can be concluded that there is no influence between motivation on employee performance

3. Work ethic variables have a positive and significant influence on employee performance, which means that there is an influence between work ethics on employee performance.

\section{References}

[1] Dewi, Nunik Lestari et al. 2018. Pengaruh Kepemimpinan Transformasional Terhadap Kinerja Karyawan Bumn Di Kota Bandung Dengan Organizational Citizenship Behaviour 
Sebagai Variabel Moderasi (Study of Pt Kimia Farma (Persero) Tbk and Pt. Bio Farma (Persero)), published in Social Science Education Journal : Volume 5, Number 1, 2018.

[2] Sunyoto, Burhaniddin. Analisis Pengaruh Locus Of Control Dan Stres Kerja Terhadap Kinerja Karyawan, published in Ejournal Manajemen and Bisnis ISSN 1693-7619 Volume:18-22017

[3] Soetopo, Imam. et al. 2018. The Influence of Transformational Leadership Style, Individual Characteristics, Work Environment on Work Motivation and Performance of State Junior High School Teachers 1 Tambelang Sampang, published in the journal Economics \& Management : Volume 05, Number. September 2, 2018

[4] Syahida, Nur and Nanik Suryani. 2018. The Influence of Work Discipline, Physical Work Environment and Work Motivation on the Performance of Village Apparatuses published in EEAJ Journal : Volume 7, Number 2, 2018

[5] Sidanti, Heny. 2015. The Influence of the Work Environment, Work Discipline and Work Motivation on the Performance of Civil Servants in the Secretariat of Madiun Regency 's Dprd, published in JIBEKA journal : Volume 9, Number 1 February 2015

[6] Maharani, Intan and Suryono Efendi. 2017. Pengaruh Budaya Organisasi, Komitmen Organisasi, Kompensasi, Dan Etos Kerja Terhadap Kinerja Pegawai Kementerian Ketenagakerjaan Republik Indonesia published in the Journal of Management Science : Volume 13, No. 2, July 2017

[7] Tucunan, Roy Johan Agung. et al 2014. The Influence of Transformational Leadership on Employee Motivation and Performance (Case Study at Pt. Pandawa), published in EJournal of Economics and Business at Udayana University : Volume 3, Number 9 of 2014

[8] Sunyoto, Burhaniddin. Analisis Pengaruh Locus Of Control Dan Stres Kerja Terhadap Kinerja Karyawan, published in Ejournal Manajemen and Bisnis ISSN 1693-7619 Volume:18-22017

[9] Kalsoom. Zohra et al. 2018. Impact Of Transactional Leadership And Transformational Leadership On Employee Performance: A Case Of FMCG Industry Of Pakistan published in Industrial Engineering Letters : Vol.8, No.3, 2018

[10] Sidanti, Heny. 2015. The Influence of the Work Environment, Work Discipline and Work Motivation on the Performance of Civil Servants in the Secretariat of Madiun Regency 's Dprd, published in JIBEKA journal : Volume 9, Number 1 February 2015

[11] Mangkunegara, Prabu Anwar. 2017. HR Evaluasi Kinerja SDM. Bandung: PT. Refika Aditama

[12] Mulyadi, Dedy and Amanda Syafitri. 2015. The Influence of Leadership and Work Motivation on Employee Performance at the Bogor Branch of Bjb Syariah Bank, published in Binaniaga Scientific Journal : Volume 11, Number. 2, 2015

[13] Ibrahim. Masud 2015. Impact Of Motivation On Employee Performance The Case Of Some Selected Micro Finance Companies In Ghana Published in United Kingdom: Vol. 3, Issue 11, November 2015

[14] Ibrahim. Masud 2015. Impact Of Motivation On Employee Performance The Case Of Some Selected Micro Finance Companies In Ghana Published in United Kingdom: Vol. 3 , Issue 11, November 2015

[15] Look , Bryan Johannes. 2014. The Influence of Leadership Style and Motivation on Employee Performance at Pt. Bank Negara Indonesia, Tbk (Manado Regional Sales), published in the journal Acta Diurna : Volume III, No.4. Year 2014

[16] Look, Bryan Johannes. 2014. The Influence of Leadership Style and Motivation on Employee Performance at Pt. Bank Negara Indonesia, Tbk (Manado Regional Sales), published in the journal Acta Diurna : Volume III, No.4. Year 2014

[17] Najoan Jecqueline Fritzie et al. 2018. The Influence of Performance Allowances on Employee Performance in the Minahasa District Agriculture Office published in AgriSocioeconomic Element : Volume 14 Number 1 January 2018 
[18] Yusuf, Nurdin. 2018. The Influence of Leadership, Responsibility, Discipline and Cooperation on Employee Performance at the University of Gorontalo published in Gorontalo Development Riview : Vol.1 No.1 April 2018.

[19] Sayuti 2018. The Influence of Leadership, Motivation and Work Ethics on the Performance of Class 1 Correctional Facilities Employees (Bapas) Banjarmasin, published in the Scientific Journal of Business Economics Volume 4, Number 2, July 2018

[20] Yantika, Yuli. et al. 2018. The Influence of Work Environment, Work Ethic, and Work Discipline on Employee Performance (Case Study on Bondowoso District Government) published in Indonesian Management and Business Journal : Volume 4, Number 2, December 2018

[21] Maharani, Intan and Suryono Efendi. 2017.Pengaruh Budaya Organisasi, Komitmen Organisasi, Kompensasi, Dan Etos Kerja Terhadap Kinerja Pegawai Kementerian Ketenagakerjaan Republik Indonesia published in the Journal of Management Science : Volume 13, No. 2, July 2017

[22] Sugiono. 2014. Quantitative, Qualitative and R\&D Research Methods . Bandung: CV. Alfabeta.

[23] Syardiansah. et al. 2018. Analysis of the Relationship Between Humans to Employee Performance published in the Journal of Information Systems : Vol.2.No.1 2018

[24] Priyatno, Duwi. 2016. Spss Handbook for Data Analysis, Data Processing \& Settlement of Statistical Cases. Yogyakarta: MediaKom

[25] Bintarti, Surya, 2015. Metodologi Penelitian Ekonomi Manajemen. Mitra Wacana Media, Jakarta. 